\title{
A survey of the diseases of marine turtles in northern Australia. II. Oceanarium-reared and wild turtles
}

\author{
J. S. Glazebrook, R. S. F. Campbell \\ Graduate School of Tropical Veterinary Science and Agriculture, James Cook University, Townsville, Queensland 4811 , \\ Australia
}

\begin{abstract}
Thirty-seven turtles were examined as part of a disease survey. They consisted of 15 oceanarium-reared turtles ( 10 Chelonia mydas, 2 Eretmochelys imbricata, and 3 Caretta caretta) and 22 wild turtles (21 C. mydas and 1 E. imbricata). Bacterial diseases of oceanarium-reared turtles were the same as those of farmed turtles with the exception of tuberculosis and adenitis (salt-secreting gland infection), which were not diagnosed. Traumatic ulcerative dermatitis (biting) and the ulcerative stomatitis-obstructive rhinitis-pneumonia disease complex were again prominent, mainly in green and loggerhead turtles. Vibrio alginolyticus and Aeromonas hydrophila were implicated once more. Peritonitis had resulted from notches made in marginal scutes for identification purposes (one turtle only). Only 2 bacterial diseases were diagnosed in wild turtles, viz. bronchopneumonia and septicaemia - toxaemia, which were secondary to heart fluke infestation. Cardiovascular flukes (Hapalotrema spp. and Learedius spp.) were found in $5 / 15(33.3 \%)$ of oceanarium-reared turtles and $9 / 22(40.9 \%)$ of wild turtles. Specimens with heavy infestations ( $>20$ flukes in the heart chambers) were severely debilitated displaying sunken eyes bilaterally, plastron shrinkage and generalized muscle wastage. Thickening and hardening of the walls of major vessels associated with the heart and pneumonia were complications. Gastrointestinal flukes (Digenea: Pronocephalidae) were restricted to the stomach of oceanariumreared turtles ( $3 / 15$ or $33.3 \%$ ) and in one case they were associated with petechial haemorrhages of the mucosa. In wild turtles they were present throughout the gastrointestinal tract and in the gall bladder $(9 /$ 22 or $40.9 \%$ affected). Barnacles (Chelonibia sp. and Platylepas sp.) were present on $2 / 15(13.3 \%$ ) and $10 / 22(45.5 \%)$ of oceanarium-reared and wild turtles respectively. Cachetic myopathy was the end result of chronic bacterial and parasitic infection in $9 / 22$ or $40.9 \%$ of wild turtles.
\end{abstract}

\section{INTRODUCTION}

There have been few reports of disease in oceanarium-reared turtles or their wild or free living counterparts. Conservation programs aimed at rearing sea turtles in captivity before releasing them have encountered disease problems. Witham (1973) lost all but 3 of 140 loggerhead (Caretta caretta) hatchlings kept at the House of Refuge Museum in Florida. A species of Bacteroides isolated from non-specific skin lesions was considered to be the primary pathogen. When a similar disease occurred in hatchlings 2 yr later, no aetiologic agent could be identified (Witham 1975), although $97 \%$ of green turtles and $81 \%$ of loggerheads were affected. In addition, Brock et al. (1976) diagnosed 6 cases of tuberculosis in Pacific green turtles (Chelonia mydas) held at the University of Hawaii.
Many zoos keep chelonians, i.e. turtles and terrapins in aquaria where they are on public display. Zwart (1968) attributed granulomatous lesions of the blood vessels of marine turtles to filarioid nematodes. Keymer (1978b) examined 7 marine turtles as part of a $10 \mathrm{yr}$ survey of the diseases of chelonians at the London Zoo. Deaths were due to colitis associated with Salmonella regent infection in a hawksbill (Eretmochelys imbricata), tuberculosis (green turtle), chronic pulmonary mycosis (Paecilomyces lilacinum isolated from green and loggerhead turtles) and trauma (loggerheads only).

In 1938, Smith \& Coates surveyed 200 wild turtles caught off the coast of Florida for fibroepithelial growths or benign tumours of the skin. A green turtle (Chelonia mydas) from the New York aquarium had previously shown similar lesions. Only 3 wild turtles had tumours and it was suggested that they may have been caused by an unknown virus. Subsequent studies 
Table 1. Origin and species of 37 turtles examined. No. affected in parentheses

\begin{tabular}{|lll|}
\hline Origin & Species affected & $\%$ \\
\hline Oceanarium-reared & & 66.6 \\
Hatchlings from Bramble Cay and Mon Repos & Chelonia mydas (10) & 13.3 \\
Beach near Bundaberg; turtles caught in & Eretmochelys imbricata (2) & 20.0 \\
$\quad$ fishing nets off Townsville & Caretta caretta (3) & \\
Wild or free-living & Chelonia mydas (21) & 95.5 \\
Wild turtles caught by Torres Strait islanders or & Eretmochelys imbricata (1) & 4.5 \\
by James Cook University for research purposes & & \\
\hline
\end{tabular}

(Smith \& Coates 1939) revealed the presence of para sitic ova (possibly from the blood fluke Hapalotrema constrictum) in more than half of the tumours examined. Nigrelli \& Smith (1943) later found leeches (Ozobranchus branchiatus) attached to similar lesions. Jacobson et al. (1989) recently described changes in cutaneous fibropapillomas on green turtles over a 6 mo period, but failed to demonstrate papillomavirus although electron-dense particles were observed in early lesions. Further, a papillomatous disease of the gall bladder (thought to be associated with the liver fluke Rhytidodoides similis) was discovered by Smith et al. (1941).

The range of diseases which occur in farmed sea turtles has been reviewed by Glazebrook \& Campbell (1990), both from the literature and a detailed study carried out on 9 islands in the Torres Strait, between Australia and Papua New Guinea. The present paper adds to the available information on turtle diseases by examining oceanarium-reared turtles from Townsville and Cairns and wild turtles from the Torres Strait.

\section{MATERIALS AND METHODS}

As with farmed turtles (Glazebrook \& Campbell 1990), the survey period extended from April 1977 to September 1980. Fifteen oceanarium reared-turtles of three different species were examined (Chelonia mydas, Eretmochelys imbricata and Caretta caretta) from an oceanarium on Magnetic Island (Table 1). These had been caught on local reefs (Fig. 1) or collected from Mon Repos Beach near Bundaberg by the Queensland National Parks and Wildlife Service. They were in generally poor condition. Twenty-two wild turtles $(21$ C. mydas and 1 E. imbricata) were captured from the wild, mostly by Torres Strait islanders. Other wild turtles (all $C$ midas) were caught by teams from

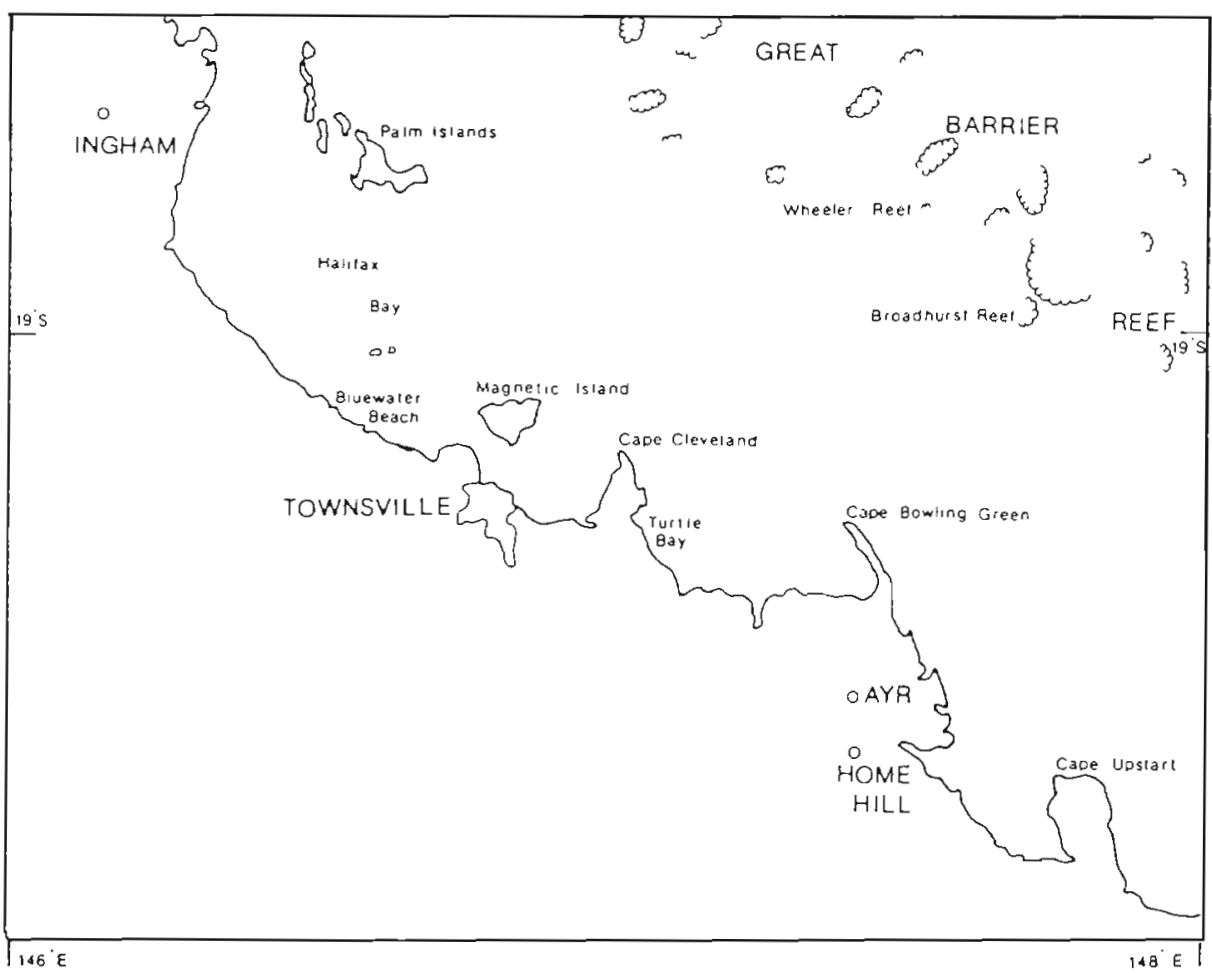

Fig. 1. Map of the Townsville area showing the location of Magnetic Island, Bluewater Beach, Turtle Bay and Broadhurst and Wheeler Reefs 
the National Parks and Wildlife Service and by James Cook University under permit (Table 1). Wild turtles were slaughtered by islanders in the traditional way, i.e. by severance of the front flippers with resultant rapid exsanguination.

\section{RESULTS}

\section{Oceanarium-reared turtles}

\section{Systemic diseases}

Five systems were affected by disease in oceanarium-reared turtles viz integumentary, sensory, digestive, respiratory and cardiovascular (Table 2).

Ulcerative skin lesions were common in hatchlings ( 2 cases recorded here) but also occurred in juveniles. Barnacles were confined to wild-caught adults. Eye lesions (keratoconjunctivitis-ulcerative blepharitis) were mostly due to contact with the side of a cement tank.

As with farmed turtles (Glazebrook \& Campbell 1990), ulcerative stomatitis was the most serious disease in hatchlings; 6/15 (or 40\%) succumbed and the usual complications (obstructive rhinitis, broncho and/ or focal pneumonia) occurred.

Five out of fifteen (or $33 \%$ of) adults were infected with cardiovascular flukes.

\section{Bacterial diseases}

Bacterial diseases (Table 3) found in oceanariumreared turtles were the same as those of farmed turtles with the exception of focal pneumonia (tuberculosis) and adenitis (salt-secreting gland infection) which were not diagnosed.

Ulcerative skin lesions were again encountered in a 6-wk-old hatchling (Chelonia mydas) from Magnetic Island and a 5-mo-old loggerhead from Brisbane (Caretta caretta). Their form and distribution were similar to those seen in farmed turtles. Cultures performed on early flipper lesions yielded Flavobacterium $\mathrm{sp}$. and Pseudomonas sp. Both turtles were housed in marine aquaria (along with up to 20 clutchmates) and fed canned or frozen fish. Although only 2 cases were studied in detail, skin lesions appeared in all hatchlings 2 to 3 wk after they were introduced to the tank. An estimated 10 to $20 \%$ of hatchlings with these lesions died during the first month of captivity. Yearlings captured in the wild and kept at the oceanarium were unaffected.

However, from observations made in the field, the ulcerative stomatitis-obstructive rhinitis-pneumonia disease complex was mainly responsible for the high mortality rate $(70$ to $95 \%$ ) of hatchlings on Magnetic Island. Two species viz Chelonia mydas and Caretta caretta were susceptible. The green turtles had originated from Bramble Cay in the Torres Strait while the loggerheads were the subject of growth studies being conducted by the Queensland National Parks and Wildlife Service in Townsville. In advanced cases, clinical signs included extreme lethargy together with severe and generalised muscular atrophy. Oral lesions were situated on the dorso-lateral aspects of the tongue and occasionally on the roof of the pharynx. They ranged in size from 1 to $4 \mathrm{~mm}$ in diameter and consisted of an accumulation of yellow, caseous material which, when debrided, left a distinct depression in the mucosa. Similar material blocked the external nare of 1 turtle and the trachea of another. The histopathological

Table 2. Chelonia mydas, Eretmochelys imbricata and Caretta caretta. Systemic diseases of 15 oceanarium-reared turtles. No. affected in parentheses

\begin{tabular}{|llr|}
\hline System & Diseases & $\%$ \\
\hline Integumentary & & 13.3 \\
$\quad$ Skin and appendages & Traumatic ulcerative dermatitis (2) & 13.3 \\
$\quad$ Carapace-plastron & External parasitism (2) & 6.6 \\
Sensory & Keratoconjunctivitis - ulcerative blepharitis (1) & 40.0 \\
Digestive & & \\
$\quad$ Alimentary tract & Ulcerative stomatitis (6) & 6.6 \\
Respiratory & & \\
$\quad$ Nasal passages & Obstructive rhinitis (1) & \\
Lungs & Bronchopneumonia (1) & 20.0 \\
Cardiovascular & Focal pneumonia (3) & 33.3 \\
$\quad$ Heart and major associated vessels & Focal endocarditis - chronic arteritis (5) & 40.0 \\
& Septicaemia - toxaemia (6) & \\
\hline
\end{tabular}


Table 3. Chelonia mydas, Eretmochelys imbricata and Caretta caretta. Bacterial diseases of oceanarium-reared turtles. No. affected in parentheses

\begin{tabular}{|c|c|c|c|}
\hline Disease & Pathogens isolated & $\begin{array}{l}\text { Species } \\
\text { affected }\end{array}$ & $\begin{array}{c}\text { Prevalence } \\
\quad \%\end{array}$ \\
\hline $\begin{array}{l}\text { Traumatic ulcerative } \\
\text { dermatitis }\end{array}$ & Flavobacterium sp. and Pseudomonas sp. & $\begin{array}{l}\text { C. mydas (2) } \\
\text { C. caretta (1) }\end{array}$ & 20.0 \\
\hline \multirow[t]{2}{*}{ Ulcerative stomatitis } & $\begin{array}{l}\text { Vibrio alginolyticus, Aeromonas hydrophila and } \\
\text { Flavobacterium sp. }\end{array}$ & C. mydas (4) & 40.0 \\
\hline & $\begin{array}{l}\text { Acinetobacter calcoaceticus and } \\
\text { Pseudomonassp. }\end{array}$ & C. caretta (2) & \\
\hline Obstructive rhinitis & Flavobacterium sp. and Pseudomonas sp. & C. mydas (1) & 6.6 \\
\hline Bronchopneumonia & Vibrio alginolyticus and Flavobacterium sp. & C. mydas (1) & 6.6 \\
\hline $\begin{array}{l}\text { Keratoconjunctivitis - } \\
\text { ulcerative blepharitis }\end{array}$ & Causal organism not identified & C. caretta (1) & 6.6 \\
\hline Peritonitis & Pseudomonas.sp. & E. imbricata (1) & 6.6 \\
\hline Septicaemia-toxaemia & Suspected on histological grounds & $\begin{array}{l}\text { C. mydas (5) } \\
\text { C. caretta (i) }\end{array}$ & 40.0 \\
\hline
\end{tabular}

changes associated with these abnormalities closely resembled those already described in farmed turtles (Glazebrook \& Campbell 1990) as did the pathogens (Vibrio alginolyticus, Aeromonas hydrophila, and Pseudomonas sp.) that were isolated from lesions. In addition, Acinetobacter calcoaceticus was recovered from the oral cavity of loggerheads.

Keratoconjunctivitis and peritonitis were diagnosed infrequently. They were caused by superficial trauma and notches in marginal scutes which are used as a means of identification by the Queensland National Parks and Wildlife Service. Septicaemia-toxaemia was closely associated with traumatic ulcerative dermatitis, ulcerative stomatitis, obstructive rhinitis and broncho- pneumonia. Degenerative changes in the kidney suggested the presence of toxins.

\section{Parasitic diseases}

Parasitic diseases are listed in Table 4. Cardiovascular flukes (Digenea: Spirorchiidae) were a prominent feature $(5 / 15$ or $33.3 \%$ infected) of larger turtles (subadults and adults) on Magnetic Island. These specimens had been caught on nearby reefs viz Middle, Broadhurst and Wheeler (Fig. 1) and kept at the oceanarium for varying lengths of time (up to $3 \mathrm{yr}$ ). Both auricles and the ventricle were occupied,

Table 4. Chelonia mydas and Eretmochelys imbricata. Parasitic diseases of oceanarium-reared turtles. No. affected in parentheses

\begin{tabular}{|c|c|c|c|}
\hline Disease & Parasite and site & Species affected & $\begin{array}{c}\text { Prevalence } \\
(\%)\end{array}$ \\
\hline $\begin{array}{l}\text { Focal endocarditis with } \\
\text { disseminated egg granulomas }\end{array}$ & $\begin{array}{l}\text { Platyhelminthes } \\
\text { Flukes (Digenea: Spirorchiidae) in the } \\
\text { circulatory system: Hapalotrema sp. }\end{array}$ & $\begin{array}{l}\text { C. Mydas (3) } \\
\text { E. imbricata (2) }\end{array}$ & 33.3 \\
\hline Gastric and intestinal flukes & $\begin{array}{l}\text { Flukes (Digenea: Pronocephalidae) } \\
\text { in the stomach and small intestine: } \\
\text { Cricocephalus sp. } \\
\text { Diaschistorchis sp. } \\
\text { Flukes (Digenea: Calcycodidae) in } \\
\text { the gall bladder: Calcodes sp. }\end{array}$ & $\begin{array}{l}\text { C. mydas (1) } \\
\text { E. imbricata (2) } \\
\text { E. imbricata(1) } \\
\text { E. imbricata (1) }\end{array}$ & 20.0 \\
\hline External parasitism & $\begin{array}{l}\text { Arthropoda } \\
\text { Barnacles (Crustacea: Coronulidae) } \\
\text { attached to the carapace and plastron: } \\
\text { Chelonibiasp. } \\
\text { Platylepassp. }\end{array}$ & $\begin{array}{l}\text { C. mydas (1) } \\
\text { E. imbricata (1) }\end{array}$ & 13.3 \\
\hline
\end{tabular}


although the parasites tended to concentrate in the auricles. Turtles with heavy infestations, i.e. $>20$ flukes in 3 chambers, displayed a severely debilitated state, i.e. sunken eyes, plastron shrinkage and generalised muscle wastage. In addition, one specimen was unable to dive and had a persistent list to one side. At necropsy, an excess of peritoneal fluid $(1.0$ to $1.5 \mathrm{ml})$ was observed, and in one case 2 to $3 \mathrm{ml}$ of pericardial fluid. The turtle with buoyancy problems showed extensive fibrosis of the medial portion of the left lung. Microscopically, the disease was characterised by multiple, diffuse egg granulomas in the supporting tissues of the brain, heart, lung, liver, kidney, spleen, urinary bladder and salt-secreting gland. The lungs and spleen contained large numbers of eggs and haemorrhage had occurred in 2 cases. Further changes in the cardiovascular system included marked hypertrophy of the walls of major afferent vessels (particularly in the lungs and spleen) and focal inflammation of the endothelium lining the heart (endocarditis). The flukes were identified as members of the Genus Hapalotrema.

Gastric flukes (Digenea: Pronocephalidae) were also found in 3 of the above turtles. They were concentrated at the junction of the crop and the stomach where many were engorged. In one case, no less than 40 flukes were associated with petechial haemorrhages in the mucosa. The same turtle had 3 flukes (Calcodes sp.) in the gall bladder.

Most of the barnacles (Genus Chelonibia and Platylepas) removed from oceanarium-reared turtles were already established when the specimens were first captured in the wild. In one extreme case, a hawksbill turtle from Nelly Bay was carrying $>200$ barnacles on the upper and lower body.

\section{Nutritional diseases}

Cachetic myopathy in oceanarium-reared turtles (6/ 15 or $40 \%$ ) was associated with chronic bacterial and parasitic infections viz ulcerative stomatitis and focal endocarditis with disseminated egg granulomas. Fish ribs were responsible for intestinal obstruction in 2 turtles $(13.3 \%)$.

\section{Diseases of wild turtles}

Systemic diseases

Only 2 systems viz. integumentary and cardiovascular were affected by disease in wild turtles, both as the result of parasites, viz barnacles and cardiovascular flukes (Table 5).
Table 5. Chelonia mydas, Eretmochelys imbricata and Caretta caretta. Systemic diseases of 22 wild turtles. No affected in parentheses

\begin{tabular}{|llr|}
\hline System & Disease & $\%$ \\
\hline $\begin{array}{c}\text { Integumentary } \\
\text { Carapace-plastron }\end{array}$ & External parasitism (11) & 50.0 \\
Cardiovascular & & \\
Heart and major & Focal endocarditis - & \\
associated vessels & chronic arteritis (17) & 77.2 \\
& Septicaemia - toxaemia (2) & 9.0 \\
\hline
\end{tabular}

\section{Parasitic diseases}

Flukes were found in the cardiovascular and alimentary systems (2 and 7 species, respectively) of wild turtles and barnacles were prominent externally (Table 6).

Flukes (Digenea: Spirorchiidae) were recovered from the heart (Fig. 2) and major associated vessels (right aortic arch and brachiocephalic artery) of 9 turtles ( $40.9 \%$ of those examined), while their eggs were detected in the organs and tissues of 17 turtles (77.2\%). All were green turtles with the exception of 1 hawksbill and only sub-adults and adults were affected. The average number of flukes per host was 36 and 2 genera were identified viz Hapalotrema and Learidius. Two turtles displayed clinical signs similar to those seen in oceanarium-reared turtles, i.e. sunken eyes, plastron shrinkage and generalised muscle wastage. Gross lesions were confined to turtles with active infections, i.e. those with flukes in the heart and/or major associated vessels. The most noticeable change was thickening and hardening of arterial walls (5 turtles) together with thrombus formation. Pneumonia was diagnosed in 2 turtles and there was an excess of peritoneal fluid in another two. Microscopic changes included acute and chronic inflammation (depending on the severity of the disease), haemorrhage (intra-cerebral), congestion, oedema and vascular and pulmonary hypertrophy.

Gastrointestinal flukes were found in the stomach, small intestine, large intestine and gall bladder of 9 wild turtles (Table 6). Infected green turtles were caught in the Torres Strait (Badu Island, Dalrymple Island and Mi Mi Islet), and a hawksbill in Nelly Bay on Magnetic Island. Two of the 7 genera identified occurred in the stomach and small intestine (Cricocephalus sp. and Desmogonius sp.), 4 in the large intestine (Angiodictyum sp., Octangium sp., Polyangium sp. and Schizamphistomum sp.) and one in the gall bladder (Rhytidodes sp.). These worms were not associated with pathological change, gross or microscopic.

Barnacles were present in 10 of the 22 wild turtles examined (Table 6). Once again, these specimens were 
Table 6. Chelonia mydas and Eretmochelys imbricata. Parasitic diseases of 22 wild turtles. No. affected in parentheses

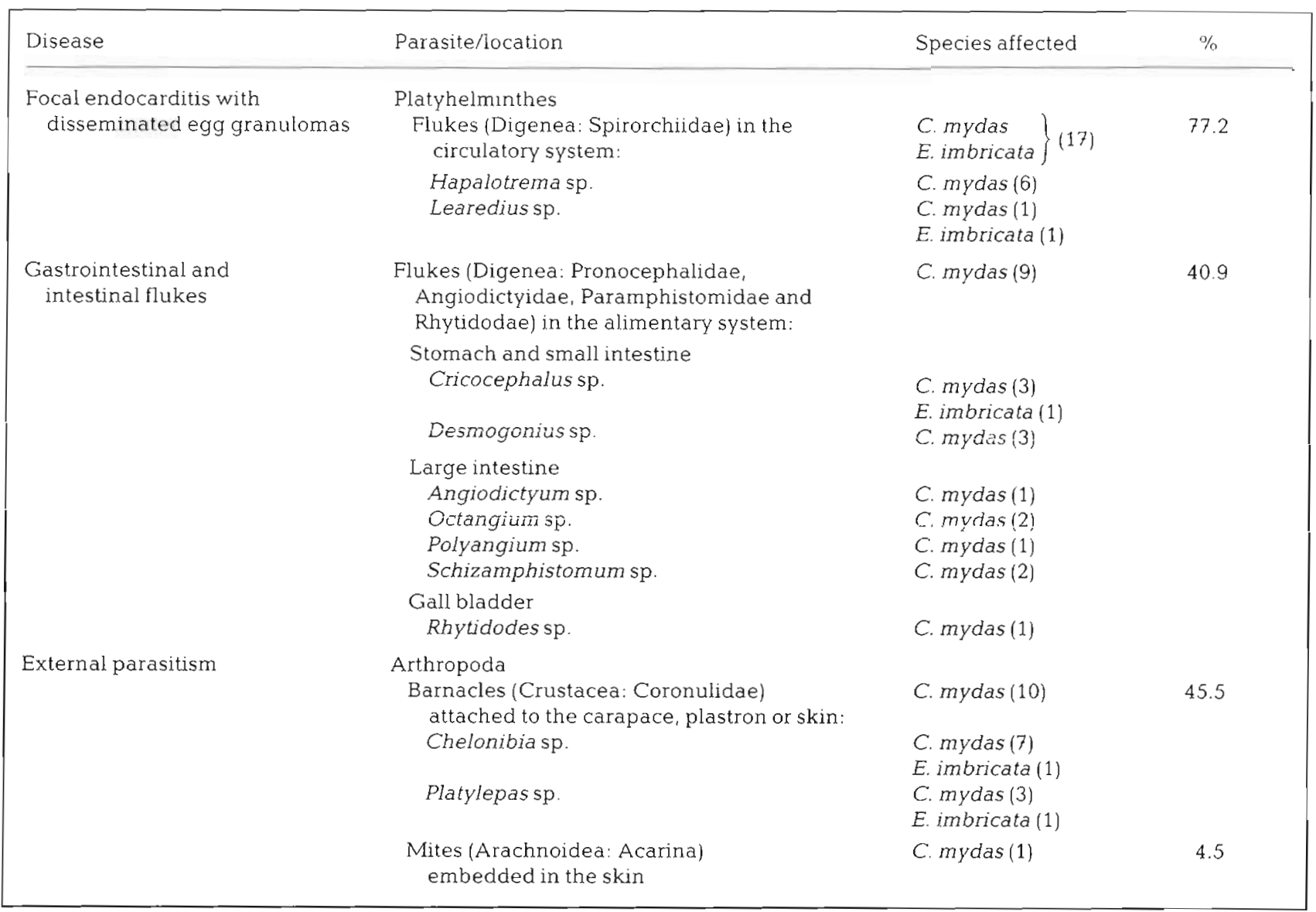

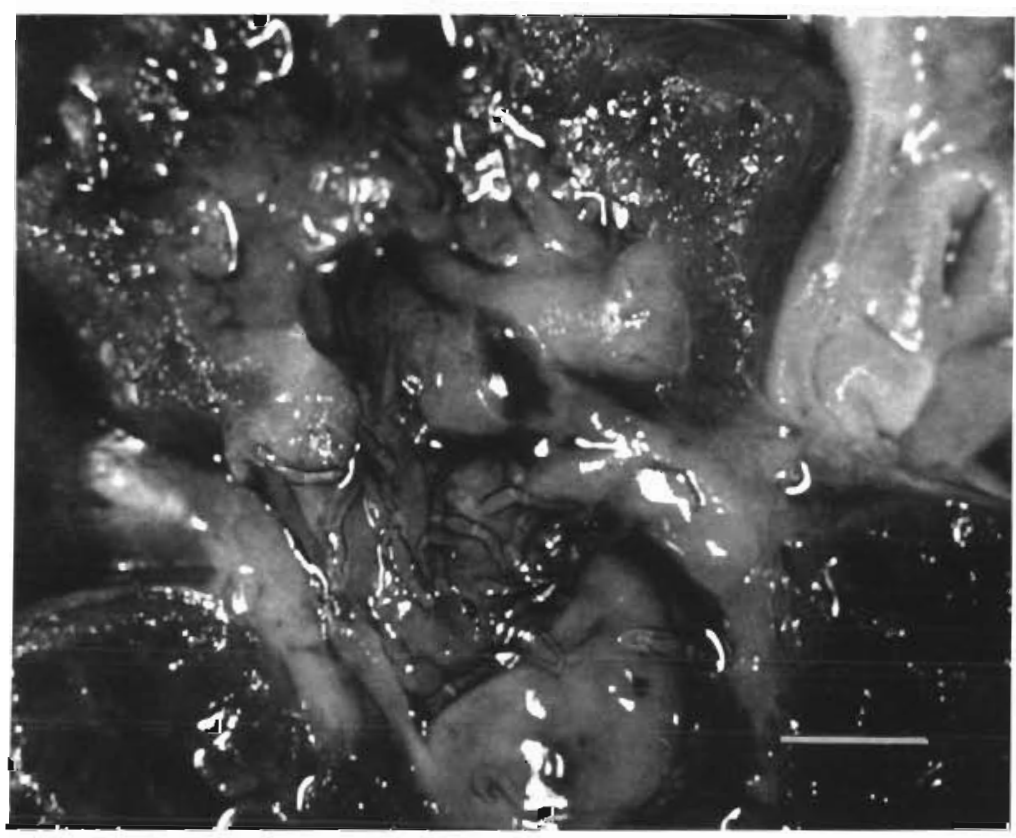

Fig. 2. Chelonia mydas. Cardiovascular flukes in the heart chambers of an adult turtle. Scale bar $=$ $5 \mathrm{~mm}$ 
from the Torres Strait (Dalrymple Island, Rennel Island and Mi Mi Islet) and Nelly Bay. Chelonibia sp. were common on the carapace and plastron while Platylepas sp. preferred the soft tissues of the neck, axillary and inguinal regions and tail. An unidentified mite was embedded in a fibrous growth $(5 \times 3 \mathrm{~cm})$ removed from the neck of a green turtle from Turtle Bay near Townsville.

\section{Bacterial and nutritional diseases}

As in oceanarium-reared turtles, cachetic myopathy occurred in association with cardiovascular fluke infestation $(2 / 22$ or $9.1 \%)$, while broncho-pneumonia and septicaemia-toxaemia $(2 / 22$ or $9.1 \%)$ were further complications of heart fluke infestation.

\section{DISCUSSION}

Bacterial diseases were important in oceanariumreared turtles and farmed turtles (Glazebrook \& Campbell 1990). The 2 populations had 7 diseases in common. Ulcerative stomatitis was again associated with a high mortality rate and except for Acinetobacter calcoaceticus the same organisms were responsible, i.e. Vibrio alginolyticus, Aeromonas hydrophila and Flavobacterium sp. A. calcoaceticus has been implicated in cases of human conjunctivitis (Baumann et al. 1968). In addition, the clinico-pathological picture was almost identical to that of farmed turtles. As in the Torres Strait farms, the disease was sometimes complicated by obstructive rhinitis and/or pneumonia. Keratoconjunctivitis was again caused by superficial trauma (this time against the side of a cement tank) and peritonitis by over-enthusiastic tagging. It was also worth noting that loggerhead turtles as well as green turtles were susceptible to traumatic ulcerative dermatitis, ulcerative stomatitis and septicaemia-toxaemia when kept in an oceanarium. Bacterial peritonitis has not been reported before in hawksbill turtles. Greek tortoises have been known to develop ulcerative stomatitis at the London Zoo (Keymer 1978a, Holt et al. 1979) and keratoconjunctivitis has also been diagnosed in aquarium-reared green and loggerhead turtles (Witham 1975, Cannon pers. comm.).

The parasitic diseases of oceanarium-reared turtles differed from those of farmed turtles in that they did not suffer from anisakiasis and ectoparasites were common (Table 4). It was also significant that cardiovascular flukes (Genus Hapalotrema) were recovered from oceanarium-reared turtles whereas only eggs were found in the tissues of farmed turtles. In addition they showed clinical signs (sunken eyes, plastron shrinkage and generalised muscle wastage) and the pathology associated with the disease was more severe (haemorrhage, an excess of pericardial or peritoneal fluid and pneumonia). Finally, $33.3 \%$ of oceanarium-reared turthes were affected compared to only $4.8 \%$ of farmed turtles. Smith \& Cotes (1939) had previously found trematode eggs in $50 \%$ of fibro-epithelial growths on green turtles at the New York Aquarium. In oceanarium-reared turtles gastrointestinal flukes occurred in the gall bladder (Calcodes sp.) as well as the stomach (Cricocephalus sp. and Diaschistorchis sp.) (Table 4). The petechial haemorrhages seen in the gastric wall of a hawksbill turtle infested with Diaschistorchis sp. have not been reported before, although Smith et al. (1941) and Sey (1977) attributed other changes (in the gall bladder and large intestine) to the presence of gastrointestinal flukes in wild turtles.

Wild turtles harboured the greatest number and diversity of parasites including 2 species of cardiovascular fluke, 7 species of gastrointestinal fluke, barnacles and mites (Table 6). Cardio-vascular flukes (Hapalotrema sp. and Learedius sp.) have been found in wild turtles in the United States, India, Puerto Rico and Australia. Loggerhead turtles as well as green and hawksbill turtles were involved. In the present series only green and hawksbill turtles were examined. Most of these reports have concentrated on a taxonomic description of the parasite(s), with little or no mention of level of infestation, anatomical location of flukes and associated clinical and pathological findings. The recovery of Learedius sp. from the heart of a hawksbill turtle represented a new host record for Australia.

Acknowledgements. Mr P. Watson of 'Marine Gardens' on Magnetic Island and Mr I. Croll of 'Reef World in Cairns, gave us the opportunity to work with oceanarium-reared turtles.

\section{LITERATURE CITED}

Baumann, P., Doudoroff, M., Stanier, R. Y (1968). Study of the Moraxella Group 1. Genus Moraxella and the Neisseria catarrhalis group. J. Bacteriol. 95: 58-73

Brock, J. A., Nakamura, R. M., Miyahara, A. Y., Chang, E. M. L. (1976). Tuberculosis in Pacific green sea turtles, Chelonia mydas. Trans. Am. Fish Soc. 4: 654-656

Glazebrook, J. S., Campbell, R. S. F. (1990). A survey of the diseases of marine turtles in northern Australia. Farmed turtles. Dis. aquat. Org. 9: 83-95

Holt, P. E., Cooper, J. E., Needham, J. R. (1979). Diseases of tortoises: a review of seventy cases. J. small Anim. Pract. 20: $269-286$

Jacobson, E. R., Mansell, J. L., Sundberg, J. P., Hajjar, L., Reichmann, M. E., Ehrhart, L. M., Walsh, M., Murru, F. (1989). Cutaneous fibropapillomas of green turtles (Chelonia mydas). J. comp. Path. 101: 39-52

Keymer, I. F. (1978a). Diseases of Chelonians. I. Necropsy survey of tortoises. Vet. Rec. 103: 548-552

Keymer, I. F. (1978b). Diseases of chelonians. II. Necropsy survey of terrapins and turtles. Vet. Rec. 103: 577-582

Nigrelli, R. F., Smith, G. M. (1943). The occurrence of leeches 
Ozobranchus branchiatus (Menzies) on fibro-epithelial tumours of marine turtles Chelonia mydas (L.). Zoologica, N. Y. 28: 107-111

Sey, O. (1977). Examination of helminth parasites of marine turtles caught along the Egyptian coast. Acta. Zool. Acad. Sci. Hung. 23: 387-394

Smith, G. M., Coates, C. W. (1938). Fibro-epithelial growths of the skin in large marine turtles Chelonia mydas (Linnaeus). Zoologica, N. Y. 23: 93-98

Smith, G. M. Coates, C. W. (1939). The occurrence of trematode ova Hapalotrema constrictum (Leared) in fibroepithelial tumours of the marine turtle Chelonia mydas (Linnaeus). Zoologica, N. Y. 24: 379-382

Responsible Subject Editor: Professor P. Zwart, Utrecht, The Netherlands
Smith, G. M., Coates, C. W., Nigrelli, R. F. (1941). A papillomatous disease of the gall bladder associated with infec tion by flukes occurring in the marine turtle Chelonia mydas (Linnaeus). Zoological, N. Y 26: 14-16

Witham, R. (1973). A bacterial disease of hatchling loggerhead sea turtles. Q. Jl Fla Acad. Sci. p. 226-228

Witham, R. (1975). Focal necrosis of the skin in tank reared turtles. J. Am. Vet. Med. Ass. 163: 656

Zwart, P. (1968). Parasitäre und mykotische Lungenaffektionen bei Reptilien. Verhandlungsbericht des $\mathrm{x}$ Internationalen Symposiums über die Erkrankungen der Zootiere. Akademie Verlag, Berlin, p. 45-48

Revised version accepted: June 22, 1990 